University of Warwick institutional repository: http://go.warwick.ac.uk/wrap This paper is made available online in accordance with publisher policies. Please scroll down to view the document itself. Please refer to the repository record for this item and our policy information available from the repository home page for further information.

To see the final version of this paper please visit the publisher's website. Access to the published version may require a subscription.

Author(s): BEN CLIFT and JIM TOMLINSON

Article Title: Credible Keynesianism? New Labour Macroeconomic

Policy and the Political Economy of Coarse Tuning

Year of publication: 2007

Link to published version: http://dx.doi.org/

10.1017/S0007123407000038

Publisher statement: None 


\title{
Credible Keynesianism? New Labour Macroeconomic Policy and the Political Economy of Coarse Tuning
}

\author{
BEN CLIFT AND JIM TOMLINSON*
}

\begin{abstract}
This article questions prevailing interpretations of New Labour's political economy and challenges the assumption within the comparative and international political economy literatures of the exhaustion of the Keynesian political economic paradigm. New Labour's doctrinal statements are analysed to establish to what extent these doctrinal positions involve a repudiation of Keynesianism. Although New Labour has explicitly renounced the 'fine tuning' often (somewhat problematically) associated with post-war Keynesian political economy, we argue that they have carved out policy space in which to engage in macroeconomic 'coarse tuning' inspired by Keynesian thinking. This capacity to 'coarse tune' is precisely what is being sought in New Labour's quest for credibility through the redesign of British macroeconomic policy framework and institutions. Our empirical focus on New Labour in government since 1997 offers considerable evidence that this search for the capacity to 'coarse tune' has been successful.
\end{abstract}

The ideas of economists and political philosophers, both when they are right and when they are wrong, are more powerful than is commonly understood. Indeed the world is ruled by little else. Practical men, who believe themselves to be quite exempt from any intellectual influences, are usually the slaves of some defunct economist. Madmen in authority, who hear voices in the air, are distilling their frenzy from some academic scribbler from a few years back.

John Maynard Keynes ${ }^{1}$

It has become something of an orthodoxy amongst analysts of New Labour's political economy that, whichever 'defunct economist' the Labour governments in Britain since 1997 have been 'distilling their frenzy' from, it is not the author of those words, John Maynard Keynes. This article seeks to interrogate and challenge the assertion that New Labour has decisively renounced Keynesianism.

The mooted repudiation of Keynesianism is often explained at least in part by a changing international political economic context with which Keynesian economic policies are decreasingly compatible. ${ }^{2}$ Gray's pessimistic account infers from the assumed centrality of neo-liberal orthodoxy to 'credibility', and the changing cost/benefit analysis of national economic policies, that 'global mobility of capital and production in a world of open economies have made the central policies of European social democracy unworkable'. ${ }^{3}$ A second aim of the article is to challenge this view, exploring how far Keynesian policies are sustainable in principle in a 'globalizing' world. We illustrate how New Labour's political economy has been developed to reconcile both the securing of credibility with

* Department of Politics and International Studies, University of Warwick; and Department of History, University of Dundee, respectively. The authors would like to thank three anonymous referees for helpful and insightful comments upon an earlier draft of this article.

1 John M. Keynes, The General Theory of Employment Interest and Money (London: Macmillan, 1964 [1936]), p. 383.

2 Anthony Giddens, The Third Way (Cambridge: Polity, 1998), pp. 16-17; John Gray, False Dawn (London: Granta, 1998).

${ }^{3}$ Gray, False Dawn, pp. 88-9. 
international financial market actors and substantial fiscal policy space to pursue domestic economic policies of a broadly Keynesian character.

In a wider context, the argument presented here challenges a prevailing orthodoxy within the comparative and international political economy literatures. References to the exhaustion of the Keynesian political economic paradigm, and to the decisive renunciation of Keynesianism (and indeed the commitment to full employment) are a familiar refrain of many authoritative works in the field. These are usually placed in the context of the breakdown of 'embedded liberalism' internationally, ${ }^{4}$ and of the rise of the New Right and monetarism ideologically. ${ }^{5}$ Hall, for example, charts the 'collapse of the Keynesian consensus' (on the left as well as the right) in Britain, and the monetarist 'triumph', in particular within the Conservative party and the City. ${ }^{6}$ He quotes Callaghan's famous 1976 conference speech as 'the obituary for Keynesianism in Britain', ${ }^{7}$ and notes elsewhere of the 1977-78 public spending cuts 'for all intents and purposes the Keynesian era was over in Britain'. 8

Similarly, McNamara describes the 'search for alternatives to traditional Keynesian policies', and a 'sense of crisis' that created 'space for an new conception of the role of government in the macroeconomy'. Monetarism, she argues, provided 'a template and a legitimizing framework for a new economic strategy that made neo-liberal, antiinflationary policies a priority rather than employment and growth objectives' ${ }^{9}$ The capital mobility hypothesis of the international political economy literature makes similar claims about the powerful constraining effect of financial capital mobility upon macroeconomic policy autonomy and activism. Allegedly, this leads governments to eschew expansionary fiscal and monetary policies in favour of tight money and balanced budgets. ${ }^{10}$

Each of these accounts doubtless contains an element of truth, but - to different degrees - they all require significant qualification. As this article demonstrates, the widely held view that Keynesianism has been exhausted is inaccurate. First, Keynesian political economy has not been wholly de-legitimized by the crisis of the 1970s. The victory of monetarism over Keynesianism was not total, as the rise of various strands of New Keynesian economic thinking demonstrates. Furthermore, macroeconomic policy activism, and in particular fiscal policy activism, remains a viable strategy and a prevalent feature of government economic policy. In this article we demonstrate that an economic strategy of a broadly Keynesian character has been pursued in Britain since 1997. At the level of economic doctrine, as well as at the level of policy practice, the enduring relevance of Keynesian macroeconomic thinking to policy is evident. This indicates that the mooted incompatibility of economic strategies inspired by Keynesian thinking with the new international political economic context of global financial markets has been exaggerated.

${ }^{4}$ Eric Helleiner, States and the Re-Emergence of Global Finance (Ithaca, N.Y.: Cornell University Press, 1994), pp. 144-5.

${ }^{5}$ Mark Blyth, Great Transformations: Economic Ideas and Institutional Change in the Twentieth Century (Cambridge: Cambridge University Press, 2002), pp. 126 and 139-51.

${ }^{6}$ Peter Hall, Governing the Economy (Cambridge: Polity, 1986), pp. 92-9, 128-30

${ }^{7}$ Hall, Governing the Economy, p. 95.

${ }^{8}$ Hall, Governing the Economy, p. 80.

9 Kathleen McNamara, The Currency of Ideas: Monetary Politics in the European Union (Ithaca, N.Y.: Cornell University Press, 1998), pp. 5-6

${ }^{10}$ See for example David Andrews, 'Capital Mobility and State Autonomy: Towards a Structural Theory of International Monetary Relations', International Studies Quarterly, 38 (1994), 193-218. For a critique, see Ben Clift and Jim Tomlinson, 'Fiscal Policy and Capital Mobility: The Construction of Economic Policy Rectitude in Britain and France', New Political Economy, 9 (2004), 515-37. 
Here, for reasons set out in the first section, Keynesianism is understood as centrally concerned with pursuing full employment, especially by means of fiscal policy. Within this framework our empirical concern is with New Labour's period of office in Britain since 1997. Having defined Keynesianism, the next section examines the debates on New Labour's relationship to Keynesianism in the light of the doctrinal statements of the architects of New Labour economic policies where they have articulated in detail how they see the world and how they perceive the role and limits of national economic policy. ${ }^{11}$ The key issue here is in what sense and to what extent these doctrinal positions involve a repudiation of Keynesianism. The third section analyses the policies actually pursued by New Labour to see both how far they conform to these doctrinal statements, and how far they can be described as Keynesian. The concluding section briefly examines how far the policies of New Labour differ from those of past Labour governments in terms of their Keynesian content, and explores the significance of all this for characterizing the political economy of New Labour.

\section{DEFINING KEYNESIANISM}

In the wider debates about the scope for social democratic policies within which discussions of New Labour's relationship to Keynesianism are often situated, the specifically Keynesian component of such policies is usually underplayed or conflated with other issues. ${ }^{12}$ Some analysts focus on the possibilities of redistributive policies, ${ }^{13}$ while others see public spending and/or taxation as the crucial issues. ${ }^{14}$ While these are central concerns in the context of debates about social democracy, they are plainly different from 'Keynesianism' in any specific sense.

To pursue the argument it is clearly necessary to define Keynesianism, but to do so is to enter a 'semantic minefield'. ${ }^{15}$ One of the problems of definition is that Keynes personally was centrally concerned with effecting a revolution in economic theory, so that policy positions are rarely at the centre of his work, and those that he did advocate were noticeably pragmatic. ${ }^{16}$ Hence his personal legacy for policy is a highly contested one: as

11 Ed Balls, 'Open Macroeconomics in an Open Economy', Scottish Journal of Political Economy, 45 (1998), 113-32; Tony Blair, the 1995 Mais Lecture, reprinted in 'Blair sets out framework to cure economic ills', Financial Times, 23 May 1995; Gordon Brown, 'Chancellor's speech at the Mansion House, 11 June 1998', www.hm-treasury.gov.uk/pub/html/press98; Gordon Brown, 'The Mais Lecture by the Chancellor Gordon Brown, 19 October 1999', www.Treasury.gov.uk/newsroom_and_speeches/press/1999_168_99.cfm; Gordon Brown, 'The Conditions for High and Stable Growth and Employment', Economic Journal, $1 \overline{11}$ (2001), 30-44; Ed Balls and Gus O'Donnell, Reforming Britain's Economic and Financial Policy: Towards Greater Economic Stability (London: Palgrave, 2002).

12 Giddens, The Third Way, p. 16

${ }^{13}$ Geoffrey Garrett, Partisan Politics in the Global Economy (Cambridge: Cambridge University Press, 1998); Mark Wickham-Jones, 'New Labour in the Global Economy: Partisan Politics and the Social Democratic Model', British Journal of Politics and International Relations, 2 (2000), 1-25; Chris Pierson Pierson, Hard Choices: Social Democracy in the $21^{\text {st }}$ Century (Cambridge: Polity, 2001); Ben Clift, 'Social Democracy and Globalization: France and the UK', Government and Opposition, 37 (2002), 466-500.

14 Dani Rodrik 'Why Do More Open Economies Have Bigger Governments?' Journal of Political Economy, 106 (1998), 997-1032.

${ }^{15}$ Colin Hay, 'Credibility, Competitiveness and the Business Cycle in "Third Way" Political Economy: A Critical Evaluation of Economic Policy in Britain Since 1997', New Political Economy, 9 (2004), 39-56, p. 40.

16 Peter Clarke, 'Keynes and Keynesianism', Political Quarterly, 69 (1998), 297-305. 
Corry and Holtham note, 'were Keynes alive he would undoubtedly have some lucrative actions for libel associated with careless use of the word "Keynesian" , ${ }^{17}$

In the early post-war period many economists and policy makers happily described themselves as Keynesians but the meaning attached to this term varied. Probably the majority aligned themselves explicitly or implicitly with the 'neo-classical synthesis', which incorporated Keynes into a broader framework of orthodox economics, providing the underpinnings for a 'consensual' view that regarded Keynes as adding to rather than overthrowing much existing economic theory. By contrast, radicals such as Joan Robinson saw this synthesis as creating a 'bastard Keynesianism', which drained Keynes's ideas of their revolutionary potential. ${ }^{18}$ Since the 1970 s, Keynesianism has become both less 'hegemonic' in economic discussion and even more diverse in interpretation. A variety of 'New Keynesianisms' has emerged, with widely divergent views of what needs to be retained and what deleted from the Keynesian canon. On the one side, the work of left Keynesians like Joan Robinson has inspired a New Keynesianism that asserts the continuing and fundamental instability of capitalism and the need for major policy reconstruction to deal with this problem. ${ }^{19}$ At the other end of the spectrum is a New Keynesianism which accepts many of the central tenets of the new classical counterrevolution in economic thought, and continues the trend of the 'neo-classical synthesis' towards integrating Keynesianism into the mainstream of economics, a mainstream that has arguably become more conservative in the last decades. ${ }^{20}$ In the early twenty-first century, Keynesianism, with qualifying adjective, has become a church so broad that its doctrinal limits are difficult to determine.

Nevertheless, some parts of the Keynesian position seem clear to us. At the core is a perception of the inherent instability of a capitalist economy, and especially its inability unaided to deliver a full use of resources. As Arestis and Sawyer summarize the position: 'our approach can be considered Keynesian in the sense that its policy implications arise from the perception of the role of aggregate demand in setting the level of economic activity and the lack of automatic forces leading a market economy to full employment' ${ }^{21}$

Our definition follows the spirit of Arestis and Sawyer, by seeing the key features of Keynesianism as the pursuit of low unemployment, which in an unstable world requires, in principle, the use of all possible policy instruments, but a pursuit which must make a realistic assessment of the context of policy making, especially the international environment. ${ }^{22}$ Here it is perhaps useful to counterpose our interpretation of Keynesianism

17 Dan Corry and Gerald Holtham, Growth with Stability: Progressive Macroeconomic Policy (London: Institute for Public Policy Research, 1995), p. 3.

18 Joan Robinson, 'What Has Become of the Keynesian Revolution?' in Joan Robinson, Collected Economic Papers, Vol. V (Oxford: Basil Blackwell, 1979), pp. 168-77.

19 Jan A. Kregel, 'The Microfoundations of the "Generalisation of the General Theory" and "Bastard Keynesianism": Keynes' Theory of Employment in the Long and Short Period', Cambridge Journal of Economics, 7 (1983), 343-61.

${ }^{20}$ For example, Greg Mankiw and David Romer, eds, New Keynesian Economics, Vol. 2, Co-ordination Failures and Real Rigidities (Cambridge, Mass.: MIT Press, 1991).

${ }^{21}$ Philip Arestis and Malcolm Sawyer, 'Keynesian Economic Policies for the New Millenium', Economic Journal, 108 (1998), 181-95, p. 181.

${ }^{22}$ In relation to the international context, the key issue is the achievement of room to manœuvre - the ability to direct national economic policy towards a goal of full employment in a manner not unduly constrained by the international economic context. Keynes's clearing union was one means to that end - and arguably the balance of payments constraints experienced by post-war governments indicated Keynes was right to highlight the potential problem. In today's radically changed contemporary context, with the prevalence of capital mobility, the issue 
to that of Colin Hay, who has provided an important, insightful and influential analysis of New Labour's economic policies. ${ }^{23}$ Most generally, we do not believe New Labour has embraced the idea of the inherent stability of the capitalist economy, and that the demand side of the economy can be left to its own devices. More specifically, Hay argues that New Labour has abandoned Keynesianism, because the latter is defined by the notion of a 'long-term trade-off between inflation and unemployment', ${ }^{24}$ and Labour has allegedly completely abandoned belief in that trade-off; as we suggest below, this is not an adequate characterization of New Labour's stance. Relatedly, we do not believe that New Labour's embrace of the NAIRU is quite as Hay depicts it. ${ }^{25}$ Secondly, for Hay, 'new Keynesianism' (which he rightly distinguishes from 'post-Keynesianism', a quite separate tradition) is synonymous with 'new monetarism' ${ }^{26}$ but as we will argue, this is not helpful, as it significantly understates the continuing adherence to Keynesian insights regarding the merits of fiscal activism, which is quite incompatible with any notion of 'monetarism'. ${ }^{27}$

For Keynes, as noted, full employment, and the accompanying economic security, was undoubtedly central to his whole approach. ${ }^{28}$ But this in turn raises the question of what is full employment. Again, Keynes was pragmatic (one might say, pessimistic) on this. For example, shortly before his death he confided to James Meade that he considered an average of 8 per cent unemployment to be appropriate. ${ }^{29}$ Thus, while any 'Keynesian' policy worthy of the name must give the highest priority to full employment, some further exploration of the meaning of this term in particular circumstances is required. ${ }^{30}$ If full employment is the key goal, what are the means to this end? Again, Keynes himself was pragmatic. For much of the inter-war period he argued that lower interest rates were the key route to expanding demand, but that given the difficulties of using monetary policy, other instruments such as fiscal policy should be used. ${ }^{31}$ In the post-war period, Keynesianism came to be associated with fiscal policy to an extent unjustified by the

(F'note continued)

of room to manœuvre in order to pursue full employment finds a rather different solution. We do not claim any similarity between New Labour's strategy in this regard and Keynes's policy prescriptions, but rather that the strategy can be interpreted as directed towards achieving the goal of room to manœuvre in the pursuit of full employment, an end of which Keynes would have approved.

${ }^{23}$ Hay, 'Credibility, Competitiveness and the Business Cycle'; see also Colin Hay, 'Negotiating International Constraints: The Antinomies of Credibility and Competitiveness in the Political Economy of New Labour', Competition and Change, 5 (2001), 269-89 and David Coates and Colin Hay, 'The Internal and External Face of New Labour's Political Economy', Government and Opposition, 36 (2001), 447-471.

${ }^{24}$ Hay, 'Credibility, Competitiveness and the Business Cycle', p. 40.

25 This concept was developed in the wake of Friedman's challenging of the long-run Phillips Curve trade-off to help explain the relationship between unemployment and inflation, and the interplay of the supply and demand sides of the economy. It represents a neutrally named alternative to Friedman's ideologically loaded concept of the 'natural' rate of unemployment. We explore the significance of the NAIRU concept, and competing interpretations of New Labour's understanding of it, below pp. 54-6.

${ }^{26}$ Hay, 'Credibility, Competitiveness and the Business Cycle', pp. 39-40.

${ }^{27}$ Each of these points is developed at greater length in the next section.

${ }^{28}$ Tony Cutler, Karel Williams and John Williams, Keynes, Beveridge and Beyond (London: Routledge, 1986).

29 James Meade, Full Employment Without Inflation (London: Employment Policy Institute and Social Market Foundation, 1994), pp. 6-7.

${ }^{30}$ Notwithstanding reservations about Labour's employment record (see below, fn. 148), for the purposes of this article the commitments and achievements of the Labour governments since 1997 with regard to employment are seen to fall within a definition of full employment.

${ }^{31}$ Donald Moggridge, Maynard Keynes: An Economist's Biography (London: Routledge, 1992), chap. 17; Robert Skidelsky, John Maynard Keynes, Vol II: The Economist as Saviour 1922-37 (London: Macmillan, 1992), pp. 130-64. 
master's own writings. This reflected continuing constraints on the use of monetary policy in combination with the expansion of government spending, which made fiscal policy immensely more powerful than before 1939. Today, we can say that fiscal policy is central to 'Keynesianism', because monetary policy is focused upon anti-inflationary goals, in a parallel fashion to much of the 1920s, when adherence to the gold standard ruled out an active expansionary monetary policy.

But fiscal versus monetary policy is not the whole issue. An active fiscal policy raises the possibility of fiscal deficits, and while accepting that deficits are by no means the sine qua non of Keynesian policy, we would argue that the possibility of their existence is crucial to Keynesianism, because of what we may call the political asymmetries of the fiscal position. Critics of Keynesianism argued that deficits threatened the unwritten 'fiscal constitution' by legitimizing government spending without equivalent levels of taxation. ${ }^{32}$ In practice this fear, it can be argued, was a phantom, because governments when they borrowed had to satisfy the demands of lenders, so a political constraint remained in the form of the conditions upon which those lenders were willing to lend. ${ }^{33}$ Governments, therefore, are constrained by forces (the need to maintain 'confidence') that are indifferent to surplus production. No government, let it be emphasized, ever lost the confidence of financial markets by producing too large fiscal surpluses. This political asymmetry means that the willingness and capacity to pursue deficit finance in appropriate circumstances is a vital part of a 'Keynesian' policy stance. ${ }^{34}$

\section{NEW LABOUR AND KEYNESIANISM: A TALE OF DEATH EXAGgERATED}

The repudiation of Keynesianism is commonly alleged against New Labour's architects. ${ }^{35}$ The starkest version of this allegation is that given by Hutton, and his argument is worth quoting in full:

New Labour has felt compelled to junk Keynes wholesale, and accept the new right consensus that budget deficit manipulation only disturbs the natural rhythms of the economy, and because all government debt eventually becomes monetised, is necessarily inflationary. High public spending and high taxation crowd out private spending and place an illegitimate burden on companies and individuals alike; there is some natural limit, around 40 per cent of GDP, which should be the cap to the public sector's role. ${ }^{36}$

These arguments in fact contrast with New Labour doctrine. ${ }^{37}$ First, Ed Balls ${ }^{38}$ and Gordon Brown explicitly do not give up the idea of fiscal discretion. The central theme

\footnotetext{
32 For example James Buchanan and Richard Wagner, Democracy in Deficit: The Political Legacy of Lord Keynes (New York: Academic Press, 1977).

33 Timothy J. Sinclair, The New Masters of Capital: American Bond Rating Agencies and the Politics of Creditworthiness (Ithaca, N.Y.: Cornell University Press, 2005), pp. 3-20.

34 James Buchanan, John Burton and Richard Wagner, The Consequences of Mr Keynes (London: Institute of Economic Affairs, 1978); Roger Middleton, Government Versus the Market (Cheltenham: Elgar, 1996), pp. 50-4 and 181-6.

35 Philip Arestis and Malcolm Sawyer, 'The Economic Analysis Underlying the "Third Way" , New Political Economy, 6 (2001), 255-78; Hay, 'Credibility, Competitiveness and the Business Cycle'; Will Hutton, 'New Keynesianism and New Labour', Political Quarterly, 70 (1999), 97-102.

${ }^{36}$ Hutton, 'New Keynesianism and New Labour', p. 100.

37 Balls, 'Open Macroeconomics in an Open Economy'; Balls and O'Donnell, Reforming Britain's Economic and Financial Policy, chap. 2.

${ }^{38}$ Ed Balls was chief economic adviser to the Treasury and Gordon Brown's closest economic council for most of the first two New Labour terms, and in 2005 became a Labour MP.
} 
of Balls's argument is the need for the creation of a framework which will allow government in the fiscal field 'constrained discretion'. ${ }^{39}$ By gaining credibility for the government's long-term policies, he argues, space is opened up for the continued use of fiscal policy in the face of the economic cycle and shocks to the economy. This is not, it should be emphasized, just an argument about allowing the automatic stabilizers to work (although they are important) but actually keeping open the option of changing policy in the face of recession. This involves a commitment to 'coarse tune' the economy, based upon the Keynesian insights of the inherent instability of the economy, and the efficacy of macroeconomic policy to counter this in pursuit of full employment. Hence the logic of the following statement: 'The scope for, and likely success of, using fiscal policy to support monetary policy during a downswing in the economic cycle is likely to depend on the soundness of the medium term fiscal position'. ${ }^{40}$

The second half of the Hutton quote is no more accurate in suggesting that New Labour is committed to a doctrine of crowding out, in which higher public spending reduces private spending. While such ideas were evident in the New Right literature of the 1970s and 1980s, they do not appear in New Labour's statements. Balls clearly argues that public spending levels can be considered separately from issues of fiscal credibility, and makes no statement about any 'natural cap', ${ }^{41}$ and Brown justifies debt reduction explicitly in terms of increased future public expenditure: 'By cutting debt we cut debt interest payments, releasing money for public services not just for one year but year on year and in a sustained way ... extra public investment comes not at the expense of prudence, but because of our prudence'. ${ }^{42}$

More sophisticated but also misleading are some aspects of Arestis and Sawyer's critique. They argue that the key underlying assumption of the Third Way is that 'the market economy is viewed as essentially stable and macroeconomic policy (particularly discretionary fiscal policy) as capable of destabilising the market economy' ${ }^{43}$ Certainly it is true that New Labour doctrine asserts that fiscal policy may be de-stabilizing. A central concern of centre left and other thinking on macroeconomic policy, particularly in the British context, has been the recognition that it can potentially do much harm, as the Lawson boom demonstrated. ${ }^{44}$ However, Labour economic policy makers do not assert that this is necessarily the case, and indeed they argue forcefully that, within the right framework of 'credibility', fiscal policy will be positively stabilizing; 'macroeconomic policy, if set correctly, should be a stabilising force' ${ }^{45}$

Furthermore, New Labour's political economy does not conceive of the market economy as essentially stable. New Labour's economic architects repeatedly refer to economic shocks, to the instability of the market economy, ${ }^{46}$ and to the need for government 'to respond flexibly to the unexpected economic events that inevitably arise

39 Balls, 'Open Macroeconomics in an Open Economy', pp. 117-25 and 129; Brown, 'The Mais Lecture by the Chancellor Gordon Brown, 19 October 1999', pp. 6-7.

${ }^{40}$ Balls and O'Donnell, Reforming Britain's Economic and Financial Policy, p. 135.

41 Balls, 'Open Macroeconomics in an Open Economy', p. 123.

42 Brown, 'The Conditions for High and Stable Growth and Employment', p. 35.

43 Arestis and Sawyer, 'The Economic Analysis Underlying the "Third Way", p. 258.

44 Brown, 'The Conditions for High and Stable Growth and Employment', pp. 36-8; Balls and O'Donnell, Reforming Britain's Economic and Financial Policy, pp. 18-23.

45 Balls and O'Donnell, Reforming Britain's Economic and Financial Policy, p. 156.

46 See, for example, Brown, 'The Conditions for High and Stable Growth and Employment', pp. 34, 39, 42, 43; Balls, 'Open Macroeconomics in an Open Economy', pp. 119-20, 124, 128, 130. 
in an increasingly integrated but more volatile global economy'; ${ }^{47}$ and elsewhere 'scope to accommodate the impact of the economic cycle and room to act in the event of exceptional economic shocks' ${ }^{48}$ Logically, this entails repudiation of the idea that a market economy is inherently stable; if this were the case, what need would there be for governments to try and find room for manœuvre for fiscal policy in time of recession?

Secondly, Arestis and Sawyer argue that in New Labour doctrine 'Fiscal policy has a passive role to play in that the budget deficit position varies over the business cycle in the well known manner, but an active fiscal policy is not required to either "fine tune" or even "coarse tune" the economy'. ${ }^{49}$ It is certainly true that renunciation of fine tuning is a leitmotif of New Labour economic statements. ${ }^{50}$ However, as noted above, it is not the case that New Labour has renounced activist fiscal policy in theory. ${ }^{51}$ Indeed the capacity to 'coarse tune' is precisely what is being sought in the quest to achieve credibility. Furthermore, as the empirical section below demonstrates, there is considerable evidence that this search for the capacity to 'coarse tune' has been successful.

Hay's critique of New Labour, as noted above, alleges a decisive abandonment of Keynesianism. ${ }^{52}$ New Labour's political economy, Hay argues, is characterized by 'the acceptance of a natural rate of unemployment, a rejection of the notion of any long-term trade-off between inflation and unemployment (and with it Keynesian economics) and an acceptance that there is no role in macroeconomic policy for adjustments in aggregate or effective demand' ${ }^{53}$ This quote raises a number of key issues that require teasing out.

First, it is not the case that New Labour embraces the idea of a natural rate of unemployment. Brown argues specifically that the idea of a fixed natural rate of unemployment consistent with stable inflation was discredited by the evidence of the 1980s'. ${ }^{54}$ Thus Brown rejects what Cross calls 'the notion of the long-run natural rate as an attractor for actual unemployment'. ${ }^{55}$ Brown and New Labour do accept the idea of a Non-Accelerating-Inflation Rate of Unemployment (NAIRU), but this is not necessarily synonymous with 'the natural rate', and certainly not with the version of the 'natural rate' doctrine to which Hay refers. ${ }^{56}$ The NAIRU theory has become influential, but it is important to differentiate between its different forms. The conception of NAIRU upon which New Labour's political economy rests is not akin to the 'natural rate' of what Corry and Holtham call, 'the hard core true believers'. 57

${ }^{47}$ Brown, 'The Conditions for High and Stable Growth and Employment', p. 34

${ }^{48}$ Balls and O'Donnell, Reforming Britain's Economic and Financial Policy, p. 158.

49 Arestis and Sawyer, 'The Economic Analysis Underlying the "Third Way", , pp. 259, 269 and 274.

${ }^{50}$ See, for example, Brown, 'The Mais Lecture by the Chancellor Gordon Brown, 19 October 1999', p. 4; Arestis and Sawyer, 'The Economic Analysis Underlying the "Third Way"'; forward to Balls and O'Donnell, Reforming Britain's Economic and Financial Policy, p. x.

${ }^{51}$ See, for example, Gordon Brown, 'Chancellor of the Exchequer's Budget Statement, 17 March 2004', http://www.hm-treasury.gov.uk/budget/budget_04/bud_bud04_speech.cfm. Interestingly, Keynes's own preference was for public investment (rather than 'normal' fiscal policy) as the appropriate agent of demand management. Keynes himself can, in our terms, be considered a 'coarse-tuner'. In correspondence with James Meade, Keynes displayed what Skidelsky calls 'a distinct bias against fiscal fine-tuning'. See Robert Skidelsky, John Maynard Keynes, Vol. III: Fighting for Britain 1937-1946 (London: Macmillan, 2000), p. 278, see also pp. 273-6.

${ }_{52}^{52}$ Hay, 'Credibility, Competitiveness and the Business Cycle'.

${ }^{53}$ Hay, 'Credibility, Competitiveness and the Business Cycle', p. 40.

${ }^{54}$ Brown, 'The Conditions for High and Stable Growth and Employment', p. 38.

55 Rod Cross, 'Natural and Unnatural Frameworks', New Political Economy, 6 (1999), 63-8, p. 68.

${ }^{56}$ Hay, 'Credibility, Competitiveness and the Business Cycle', p. 40.

${ }^{57}$ Corry and Holtham, Progressive Macroeconomics, p. 13. 
Many economists are cautious about the 'natural rate' approach's bolder assumptions. As Corry and Holtham point out, 'there is no reason to think the NAIRU is stable or invariant to the actual unemployment rate'. The policy implication is clear: 'Increasing unemployment to reduce inflation will not, on historical evidence, be a temporary affair. If and when the economy returns to the NAIRU after a significant recession, the NAIRU will be higher; some loss of employment will be permanent' ${ }^{58}$ Cross highlights that '[1]ittle or no evidence regarding the consistency between the medium-run behaviour of unemployment and convergence to the long run natural rate has been forthcoming, so the theory remains an article of faith rather than of reason or demonstration' ${ }^{59}$ As Corry and Holtham argue, 'while economists see the notion of a NAIRU to organise their thinking about the economy, it is not an operational concept for policy' ${ }^{60}$ This view, Alan Budd noted in 1999, was shared by the Monetary Policy Committee of the Bank of England. ${ }^{61}$

Stiglitz tries to unpick some of the underlying 'natural rate' assumptions that those who are not 'hard core true believers' ${ }^{62}$ question. He notes:

in proposing the concept of the natural rate of unemployment, Milton Friedman separated the demand-management choices of policymakers from the constraints on those choices. While the argument here agrees with Friedman that supply-side labour market factors like demography are of primary importance, the concept of hysteresis suggests that rather than macroeconomic policymakers being faced with a NAIRU given to them solely by the supply side of the economy, the natural rate also depends on the evolution of aggregate demand. In short, Friedman's dichotomy may be overstated. ${ }^{63}$

There is, within New Labour's analysis, recurrent recognition of the feedback effect of macroeconomic policy (and errors therein) into actual unemployment, and thus a rejection of Friedman's dichotomy. Discussions of 'hysteresis' also form part of the analysis, ${ }^{64}$ although New Labour are equivocal regarding the evidence of hysteresis effects. ${ }^{65}$ Yet the notion of the interaction of supply and demand sides, and the relevance of both to explaining unemployment pervades New Labour writings on the topic. As Brown points out, 'we recognise that the role of a macro economic policy is not simply to bear down on inflation but by creating a platform of stability to promote growth and employment ... in other words, macroeconomic and microeconomic policy are both essential - working together - to growth and employment'. ${ }^{66}$ Meanwhile Blair, in his 1995 Mais Lecture observed, 'the control of inflation is vital in its own right. But what is even more crucial is that, in practice, the "classical" split between inflation and output cannot be maintained. Temporary failures over inflation have permanent effects on the real economy - on output and jobs' and, later, '[the Tories] are wrong to see these instruments as separate or separable - they are in fact complementary. The one should support the other; the one should compensate for the failings of the other' ${ }^{67}$

${ }^{58}$ Corry and Holtham, Progressive Macroeconomics, pp. 12-13.

${ }^{59}$ Cross, 'Natural and Unnatural Frameworks', p. 65.

${ }^{60}$ Corry and Holtham, Progressive Macroeconomics, p. 12.

${ }^{61}$ Alan Budd, 'The MPC and the Natural Rate: A Theoretical Not an Operational Concept', New Political Economy, 6 (1999), 69-73, p. 69.

${ }^{62}$ Corry and Holtham, Progressive Macroeconomics, p. 13.

${ }^{63}$ Joseph Stiglitz, 'Reflections on the Natural Rate Hypothesis', Journal of Economic Perspectives, 11 (1997), $3-10$, p. 8.

${ }_{64}^{64}$ Balls and O'Donnell, Reforming Britain's Economic and Financial Policy, pp. 30-1.

${ }^{65}$ Balls and O'Donnell, Reforming Britain's Economic and Financial Policy, p. 78.

${ }^{66}$ Brown, 'The Mais Lecture by the Chancellor Gordon Brown, 19 October 1999'.

${ }^{67}$ Blair, 'The 1995 Mais Lecture'. 
New Labour's more relaxed NAIRU assumptions clearly accept that structural supply-side issues are of central importance, but they also admit that demand shocks have a major impact. Brown notes that 'demand management alone cannot deliver high and stable levels of employment'. ${ }^{68}$ This qualifier has important implications for the characterization of New Labour's political economy. It is considerably more 'Keynesian' in this regard than is often recognized. New Labour's analysis of the NAIRU does not imply, as the 'natural rate' of the hard core true believers does, that there is no role for macroeconomic policy.

Hay is certainly right that the rejection of the long-run inflation/unemployment trade-off is integral to New Labour doctrine. ${ }^{69}$ New Labour economic policy makers are at pains to situate their analysis and policy discussions within the contemporary macroeconomic policy mainstream. For example, Brown refers explicitly to Friedman's 1968 Presidential Lecture to the American Economic Association, and accepts - along with mainstream macroeconomic thinking - Friedman's 'diagnosis' of the absence of a long-term trade-off between inflation and unemployment. ${ }^{70}$ This admiration is shared in Balls and O'Donnell's volume, which notes 'the economics profession owes a debt of gratitude towards Milton Friedman' ${ }^{71}$ and elsewhere situates the discussion of the output-inflation trade-off 'in line with the consensus amongst economists'. ${ }^{72}$

However, as the preceding discussion of the NAIRU has demonstrated, the consequences of this doctrinal rebuttal are less clear cut than Hay suggests. The framing of the discussion continues to take issue with bolder assertions of Friedman's case. Thus Balls and O'Donnell's praise is immediately followed by the qualification 'this is not, of course, to agree with those who concluded in the 1970s that, because people's expectations are entirely rational and forward-looking, there is not even a short-run trade-off between unemployment and inflation, or that there is a "natural rate" of unemployment which is not affected by macroeconomic policy'. ${ }^{73}$

In part, the consequences of the rejection of the long-run inflation/unemployment trade-off rely on that elusive notion 'the long run'. Keynes famously asserted that 'in the long run we are all dead', his point being that to deny the need for policy activism in the short run on the basis that eventually the economy would recover was hardly a satisfactory or sustainable view. ${ }^{74}$ Under New Labour a similar view seems to have prevailed: that whatever view one might have of long-run tendencies, policy 'cannot afford to wait'. Certainly, to reiterate, it has not led (even in doctrine) to the view that there is no role 'for adjustments in aggregate or effective demand' ${ }^{75}$ Brown's position on this is quite clear and is asserted more than once. First, as noted above, 'Because there is no long-term trade-off between inflation and unemployment, demand management alone cannot deliver high and stable levels of employment' ${ }^{76}$ and elsewhere 'Since there is no long-term trade

${ }^{68}$ Brown, 'The Conditions for High and Stable Growth and Employment', p. 31, emphasis added.

69 Balls, 'Open Macroeconomics in an Open Economy', p. 118; Brown, 'The Mais Lecture by the Chancellor Gordon Brown, 19 October 1999', p. 5.

${ }^{70}$ Brown, 'The Conditions for High and Stable Growth and Employment', p. 32.

71 Balls and O'Donnell, Reforming Britain's Economic and Financial Policy, pp. 30-1.

72 Balls and O'Donnell, Reforming Britain's Economic and Financial Policy, p. 205.

73 Balls and O'Donnell, Reforming Britain's Economic and Financial Policy, p. 31.

74 J. M. Keynes, A Tract on Monetary Reform: Collected Writing of John Maynard Keynes, Vol. IV (London: Macmillan, 1971 [1923]), p. 65.

75 Hay, 'Credibility, Competitiveness and the Business Cycle', p. 40.

76 Brown, 'The Conditions for High and Stable Growth and Employment', p. 31, emphasis added. 
off between inflation and unemployment, delivering full employment requires a focus on not just one but all the levers of economic policy'. ${ }^{77}$ The import of these statements should be clear. They do not accept Friedman's dichotomy outlined by Stiglitz above, and therefore do not amount to the embrace of whole-hog monetarism in which manipulation of demand impacts only on the price level. Instead, they carefully reserve a role for demand management in determining the level of employment, albeit alongside supply-side policy. We return to this crucial issue of the unemployment/inflation trade off in the next section which looks at policy in practice.

The three examples above suggest that critics of New Labour's economic doctrine have not provided an adequate account of that doctrine's characteristics. Such an account would start with the term 'credibility', which in many ways is the keystone of the arch. As Blair noted in relation to monetary policy as early as 1995, 'more important than whether a particular decision is right or wrong on interest rates - which can be a fine matter of judgement - is that the system itself has credibility'. ${ }^{78}$ In similar vein, Brown states 'the discretion necessary for effective economic policy is possible only within a framework that commands market credibility'. ${ }^{79}$ Balls quotes the now governor of the Bank of England Mervyn King in noting, 'credibility is the elusive elixir of modern macroeconomics' ${ }^{80}$ Understanding why this term is so crucial is difficult, because, while it is a concept that has increasingly been deployed within economic analysis, it also gains its significance from its status as a requirement imposed on policy makers by structural changes in the world economy. As Balls argues "changes in both the world economy and our economic understanding of it over the past twenty years mean that policymakers must adjust to new ways of making decisions'. ${ }^{81}$

Clearly one legitimate reading of such statements is that New Labour's ideologues accept that financial markets make sound judgements on government policies; in other words that policies that are credible to such markets are the correct policies in their own right. ${ }^{82}$ But while such a view is not to be dismissed, it can be countered by a rather different account which sees the focus on credibility as largely driven by a 'recognition of necessity' rather than adherence to any particular economic doctrine. The 'necessity' here is, of course, that of recognizing the role of free international movement of capital in constraining national economic policies. Gordon Brown's words may be construed as supporting such a view: "Neither the old "fine tuning" of the past, which appeared to trade off inflation for growth, nor the rigid monetary targets of the 1980s, made sense in newly liberalised capital markets'. ${ }^{83}$

This issue of how we are to understand New Labour's belief in the constraining effects of globalized capital markets has been much explored. The way in which the term 'globalization' was deployed by New Labour was recognized early on to be a key rhetorical ploy, aimed at persuading listeners of the limited room for manœuvre in economic policy. ${ }^{84}$

77 Brown, 'The Conditions for High and Stable Growth and Employment', p. 32.

78 Blair, 'The 1995 Mais Lecture'.

79 Brown, 'The Mais Lecture by the Chancellor Gordon Brown, 19 October 1999'.

${ }^{80}$ Balls, 'Open Macroeconomics in an Open Economy', p. 120.

81 Balls, 'Open Macroeconomics in an Open Economy', p. 114.

82 Arestis and Sawyer, 'The Economic Analysis Underlying the "Third Way", p. 266.

83 Brown, forward to Balls and O'Donnell, Reforming Britain's Economic and Financial Policy, p. x; Brown, 'The Mais Lecture by the Chancellor Gordon Brown, 19 October 1999', pp. 5-6.

${ }^{84}$ Clift, 'Social Democracy and Globalization: France and the UK', pp. 470-5 and 479-82; Colin Hay and Ben Rosamond, 'Globalization, European integration and the Discursive Construction of Economic Imperatives', 
Colin Hay shows that there has been little consistency in New Labour circles as to whether the constraints imposed by globalization are to be welcomed as preventing error by national governments, or reluctantly acceded to as simply reflecting hard-headed, realistic perceptions about how the world really is. ${ }^{85}$

Balls gives considerable attention to precisely what policy constraints flow from 'globalized capital', and his argument draws on (the then unpublished) work of Mosley to suggest that participants in these capital markets are interested in only a very narrow range of macroeconomic indicators - above all, current and projected inflation rates and fiscal deficits. ${ }^{86}$ The implication Balls draws from this work is very significant; that, as long as they retain credibility with respect to these two indicators, national governments are pretty much free to do as they wish in economic policy decisions such as: "the tax/spending share of GDP, the corporate tax rate, the level of the minimum wage or the toughness of competition policy to name but four' ${ }^{87}$ In this account, 'credibility' can coexist with a very substantial room for manœuvre in a range of policy areas including fiscal policy, and indeed is wholly compatible with 'coarse tuning'. ${ }^{88}$

Another way of approaching this issue is in the framework of 'rules versus discretion'. Central to the critique of 'Keynesianism' has been the argument that it legitimized a destabilizing excess of discretion for government policy, and that it needs to be replaced by a rules-based system which ties governments tightly down. Plainly, both doctrinally and practically New Labour has embraced part of this argument. Brown explicitly attacks 'fine-tuning', ${ }^{89}$ and the commitment to an inflation target combined with independence of the Bank of England to pursue that target as it sees fit clearly removes a deal of government discretion. But we should not overstate the strength and significance of this embrace.

Corry and Holtham invoke the Homeric legend of Odysseus and the Sirens which has acquired a certain currency in discussions of these issues ${ }^{90}$ to illustrate how a focus on a policy framework which secures credibility can 'severely limit governmental discretion'. 91 From a very different perspective, Gill notes how a 'new constitutionalism', steeped in a 'disciplinary neoliberal discourse', constrains economic policy making, favouring 'tight monetary and financial discipline' and 'strict control over fiscal policy'. ${ }^{92}$ In fact, in practice, any policy regime will be a combination of both rules-based and discretionary

(F'note continued)

Journal of European Public Policy, 9 (2002), 147-67, pp. 148, 154-6 and 158-9; Paul Hirst, 'Has Globalisation Killed Social Democracy?' Political Quarterly, 70 (1999), 84-96; Paul Hirst and Graham Thompson, Globalization in Question, 1st edn (Cambridge: Polity, 1996).

${ }^{85}$ Hay, 'Negotiating International Constraints', pp. 272-5 and 280-2.

${ }^{86}$ Balls, 'Open Macroeconomics in an Open Economy', p. 123; Layna Mosley, 'Room to Move: International Financial Markets and National Welfare States', International Organization, 54 (2000), 737-73, and Global Capital and National Governments (Cambridge: Cambridge University Press, 2003); see also Ben Clift and Jim Tomlinson, 'Fiscal Policy and Capital Mobility: The Construction of Economic Policy Rectitude in Britain and France', New Political Economy, 9 (2004), 515-37.

87 Balls, 'Open Macroeconomics in an Open Economy', p. 123.

88 Cf. Arestis and Sawyer, 'The Economic Analysis Underlying the "Third Way", p. 262.

89 See, for example, Brown, 'The Conditions for High and Stable Growth and Employment', pp. 32-3 and 35 .

90 Corry and Holtham, Progressive Macroeconomics, pp. 25-7; see also Stephen Gill, 'European Governance and New Constitutionalism: Economic and Monetary Union and Alternatives to Neo-Liberalism in Europe', New Political Economy, 3 (1998), pp. 5-26, p. 18.

91 Corry and Holtham, Progressive Macroeconomics, p. 25.

92 Gill, 'European Governance and New Constitutionalism', p. 9. 
elements. One may predominate, but never to the exclusion of the other. Even the European Central Bank (ECB), widely regarded as the ideal-typical rules-based regime, in its operation involves discretion. As the chief economist of the ECB, Otmar Issing, and his colleagues have noted, 'the distinction between rules and discretion has ... been differentiated from that between active and passive policies. Rules do not necessarily imply fixing once and for all the policy instruments; they typically involve changing the instrument in response to the evolution of the economy, as long as change occurs in a predetermined way. ${ }^{93}$

In hindsight, the structural and inexorable character of the fiscal constraints highlighted by Gill has been overstated. As Annesley and Gamble note 'a rules-based system does not in itself exclude a social democratic programme, though neither does it guarantee it' ${ }^{94}$ As it turned out (see the empirical discussion below), New Labour governments have not been as tightly bound to the mast of fiscal rectitude, to borrow Gill's analogy, ${ }^{95}$ as it had first appeared. Thus the rejection of 'fine-tuning' both rhetorically and practically has not involved the rejection of demand management ('coarse tuning'). More broadly, New Labour has not taken us back to the (purported) rules-based inflexibility of the pre-1914 gold standard, where, in principle, domestic policy was wholly subordinate to international gold flows. Indeed, as has been argued elsewhere, ${ }^{96}$ a carefully designed credibilityenhancing rules-based regime can, under certain circumstances, expand room to manœuvre.

Alongside credibility in the key words in New Labour's lexicon is 'stability'. The two terms are intimately related because stability is defined as low inflation and 'sound' public finances, and these are the policies which deliver credibility. ${ }^{97}$ What is interesting here is the dual rationale offered for such an emphasis on stability, for not only is it the path to credibility, but also the path to higher investment. Thus a key proposition of New Labour economics is that the investment deficiency they (along with so many of their critics) diagnose is put down to demand instability. Balls justifies this with the assertion: "As Keynes might say now, there is nothing so damaging for the "animal spirits" of business investors than repeated cycles of boom then bust' ${ }^{98}$ For New Labour preventing boom and bust is the key to higher investment (and hence faster growth and higher employment) alongside, but an important accompaniment to, supply-side reform.

As with New Labour's discussion of credibility, the focus on stability is open to quite widely divergent interpretations. On one view, New Labour's position implies that the private sector can be relied on to supply higher investment and hence jobs and growth as long as governments pursue appropriate policies. This is certainly a legitimate reading of some of the economics literature that New Labour ideas draw upon. ${ }^{99}$ However, this is not a full characterization of New Labour's political economy, and notably underplays the

93 Otmar Issing, Vitor Gaspar, Ignazio Angeloni and Oreste Tristani, Monetary Policy in the Euro Area (Cambridge: Cambridge University Press, 2001), p. 34.

${ }_{94}$ Claire Annesley and Andrew Gamble, 'Economic and Welfare Policy', in Martin J. Smith and Steve Ludlam, eds, Governing as New Labour (Basingstoke, Hants: Palgrave, 2003), pp. 144-60, at p. 146.

95 Gill, 'European Governance and New Constitutionalism', p. 18.

96 Clift and Tomlinson, 'Fiscal Policy and Capital Mobility'.

97 Brown, 'Chancellor's Speech at the Mansion House, 11 June 1998'; Brown, 'The Mais Lecture by the Chancellor Gordon Brown, 19 October 1999'; Brown, 'The Conditions for High and Stable Growth and Employment'.

98 Balls, 'Open Macroeconomics in an Open Economy', p. 115.

99 Arestis and Sawyer, 'The Economic Analysis Underlying the "Third Way", pp. 259-62. 
repeated emphasis highlighted above within New Labour doctrine on economic shocks, and inherent instability of the market economy. If one accepts, as New Labour writers do, that the economy is subject to unexpected shocks and cycles, then the importance given to stability can justify policy activism in response to destabilizing forces. ${ }^{100}$

Brown has set out the centrality of the case for stability in considerable detail. ${ }^{101} \mathrm{He}$ argues that, as in the 1940s, the key aims of economic policy are growth and full employment. The key issue for him is the nature of the policies needed to deliver these goals in the conditions of the beginning of the twenty-first century. Stability, he argues, was recognized as a necessary condition in the 1940s, and he cites the 1944 White Paper to this effect: 'action taken by the government to maintain employment will be fruitless unless wages and prices are kept reasonably stable. This is of vital importance to any employment policy'. ${ }^{102}$ But, he argues, policy makers in the years after 1944 failed to secure such stability because they misapplied Keynes when they fine-tuned the economy rather than securing the conditions for long-term stability. Hence:

The stop-go policies which were wrongly said to be Keynesian attempted to tackle high unemployment and slow growth by pulling the macroeconomic levers but reflected an approach Keynes thought appropriate for depression bound economies where the confidence of the "animal spirits" was low. The mistake was to apply this prescription universally ... ${ }^{103}$

Thus Brown seeks to argue that the 1944 White Paper, drawing on Keynes's insights, accurately set out the conditions for full employment (including especially stability), but that by misapplying these analyses policy makers in the 1950s and 1960s delivered short-termism and instability. In the Thatcher period, Brown notes, there was a complete failure to pursue stabilizing policies and eventually, in the late 1980s, a policy reversion to short-termism. ${ }^{104}$ For Brown, therefore, 'it is this government that, rejecting short-termism - not least the crude "Keynesianism" of past economic approaches - is seeking to draw on the best of Keynes' insights about political economy and put a modern Keynesian approach into practice'. ${ }^{105}$

How may we judge this claim for a Keynesianism adjusted to today's circumstances? Is it just a rhetorical device seeking to gain authority for a policy by invoking an ancestry which has really been repudiated? First, the adjustment of policy prescriptions to changing conditions has always been a feature of Keynesian political economy. Much commentary on Keynes himself has pointed out how his was not a single unchanging doctrine from which one set of consistent policy prescriptions emerged. As Winch notes of Keynes' moving position on the question of revenue tariffs in 1930-31, Keynes 'was the first to admit the irrelevance of the revenue tariff after the abandonment of the gold standard ... Keynes was driven out of the free trade camp by his responsiveness to the pressure of immediate policy circumstances. ${ }^{106}$ In Leijonhufvud's assessment, Keynes's

100 See, for example, Balls and O'Donnell, Reforming Britain's Economic and Financial Policy, pp. 157-8.

101 Brown, 'The Mais Lecture by the Chancellor Gordon Brown, 19 October 1999'; Brown, 'The Conditions for High and Stable Growth and Employment'.

102 Brown, 'The Mais Lecture by the Chancellor Gordon Brown, 19 October 1999', p. 2.

103 Brown, 'The Conditions for High and Stable Growth and Employment', p. 37.

104 Brown, 'The Mais Lecture by the Chancellor Gordon Brown, 19 October 1999', p. 4.

105 Brown, 'The Conditions for High and Stable Growth and Employment', p. 37.

106 Donald Winch, Economics and Policy (London: Hodder \& Stoughton, 1969), p. 151. Winch cites many other examples of how the Keynesian approach evolved; 'in the course of acquiring [policy-making] experience additional problems have arisen which have made it necessary to modify and refine both the aims and methods 
policy writing showed a great ability and readiness to adapt to changing political and economic circumstances, and 'Keynes' judgements of what was politically feasible at the time ... coloured his writings to an extent that more academically oriented economists have not always fully appreciated.' 107

Brown accepts the key Keynesian proposition that 'there could be a low-demand high-unemployment equilibrium for an economy', ${ }^{108}$ but, he argues, the problem has been the over-generalization of such a diagnosis to periods when it did not apply. The ambiguity here is that such an argument might be seen as a classic rhetorical trope: 'I agree in principle with this proposition, but it doesn't apply in this case', which is just a way of avoiding demonstrating the inadequacy of the starting proposition. But equally, no Keynesian, however fervent, would argue that Keynes's unemployment equilibrium is a permanent condition and, if so, it must be allowed, as Brown suggests, that sometimes it will be the wrong starting point for policy. Thus, for example, most Keynesian economists in the 1950s and 1960s recognized that Britain's economic problems were no longer those of the chronic unemployment of the 1920s and 1930s, and that new policy ideas were needed. ${ }^{109}$

Brown's rejection of the view that Keynes's 'special case' is currently relevant does not lead to a rejection of all macroeconomic policy. As noted above, the polemical force of this argument is aimed against sole reliance on macro policy, and in favour of a combination of macro and micro. ${ }^{110}$

This section has suggested, first of all, that New Labour's economic doctrines are less reducible to some clear-cut theoretical dogma than some critics have suggested. Hay, for example, sees New Labour's policy as 'consistently drawn' from a particular academic theory. ${ }^{111}$ Against this we argue that policy is never reducible to a particular doctrine. This is because the economic thinking which underpins New Labour's political economy has been drawn from a number of sources. New Labour's critics considered here have focused on the more neo-classical and new classical refrains within New Labour's doctrinal statements about economic policy, but have paid insufficient attention to how these are counter-posed with more Keynesian elements. They have also not spelt out how the overall package is deployed and set out in such a way as to create 'policy space' and justify substantial macroeconomic policy activism which owes a considerable debt to Keynesian thinking.

The drawing of inspiration from more than one macroeconomic policy tradition is arguably the consequence of the inescapable requirement of economic policy discourse to both draw upon but also go beyond the purely theoretical. In particular, such discourse almost inevitably has to deal with perceived institutional arrangements that are never fully

(F'note continued)

of economic management' (p. 282), and elsewhere 'flexibility in response to changes in economic conditions is vital to modern fiscal policy’ (p. 314). See also pp. 259-63, 281-2, 315-17, 321 for further examples of pragmatic shifts in policy stance in response to changing conditions.

107 Axel Leijonhufvud, On Keynesian Economics and the Economics of Keynes (Oxford: Oxford University Press, 1968), pp. 19-20, see also pp. 401-17.

108 Brown, 'The Conditions for High and Stable Growth and Employment', p. 37.

109 Roger Middleton, Charlatans or Saviours? Economists and the British Economy from Marshall to Meade (Cheltenham, Gloucs.: Elgar, 1998), pp. 201-52.

${ }^{110}$ Brown, 'The Conditions for High and Stable Growth and Employment', pp. 31 and 37.

111 Hay, 'Credibility, Competitiveness and the Business Cycle in "Third Way" Political Economy', pp. 40, 49, 50. 
captured by economic theory. The influence of economic theory upon actual policy, and indeed the doctrinal statements of policy makers, is always mediated, both by events and by recognition of the material and ideational constraints under which policy makers operate. As Watson observes,

the concerns of the economic modeller are very different to those of the policy-maker. The day-to-day changes in party political fortunes, allied to the governing party's attempts to forge a sustainable long-term electoral bloc, represent the essence of the policy-maker's decision matrix. However, they are of no concern to the modeller ... the policy-maker exercises influence over actual economies, while the modeller inhabits a world of abstract theory. ${ }^{112}$

This leads to the second conclusion of this section: that the doctrine contains ambiguities, not because the formulators of the doctrine are muddled thinkers, but because the forging of a political economic strategy for governing is a different enterprise from formulating a cogent economic theory. Policy makers are bound by the constraints highlighted above, by institutional context and by the need to secure credibility. This leads them to insert a dose of what Annesley and Gamble term 'macroeconomic pragmatism (the rejection of doctrinaire approaches to economic management) ${ }^{113}$ into the policy mix.

\section{NEW LABOUR IN GOVERNMENT: FISCAL POLICY, FULL EMPLOYMENT AND KEYNESIANISM}

In moving from doctrine to policy we must be aware of the issues that make such a transition less than straightforward. To rephrase an old adage, policy makers make policy decisions but not in circumstances of their own choosing. In particular, we must note the dangers of seeing doctrine as an accurate guide to what governments will do in office. As is well known, this was a danger not always avoided in the academic discussions of 'Thatcherism'. Many were the accounts of this alleged phenomenon which constructed a coherent 'New Right' doctrine that proved far more consistent than the actual policies pursued after $1979 .{ }^{114}$ Such a disparity may arise because the doctrine is far less coherent than commentators have suggested. In the case of New Labour we have argued that focusing on a single ('neo-liberal' or 'monetarist') characterization is misleading and unhelpful given the range of macroeconomic thinking upon which New Labour has drawn, ignoring as it does significant Keynesian elements.

Furthermore, the particular circumstances in which governments take power will make some elements of doctrine appear more pertinent and important than others. The centrality of the search for credibility, for example, is certainly evident in the initial period. The decision to grant independence to the Bank of England is perhaps the most dramatic evidence of this. Inflation targeting began under the Conservatives in 1993, but Labour's crucial reform was to give the Monetary Policy Committee responsibility for setting interest rates within the context of that target (which was now explicitly symmetric). The aim was to give the inflation target greater credibility by making it impossible for

\footnotetext{
112 Matthew Watson, 'Endogenous Growth Theory: Explanation or Post Hoc Rationalisation for Policy?' British Journal of Politics and International Relations, 6 (2004), 543-51, p. 544.

113 Annesley and Gamble, 'Economic and Welfare Policy', p. 149.

114 Sam Aaronovitch, Thatcherism (London: Lawrence and Wishart, 1980); Stuart Hall and Martin Jacques, eds, The Politics of Thatcherism (London: Lawrence and Wishart, 1983); Paul Hirst, After Thatcher (London: Collins, 1989); cf. Jim Bulpitt, 'The Discipline of the New Democracy: Mrs Thatcher's Domestic Statecraft', Political Studies, 34 (1986), 19-39.
} 
politicians to over-ride evidence of inflationary pressure leading to lowering interest rates in order to achieve short-term goals. ${ }^{115}$

On the fiscal side, the government committed itself to sticking to the Conservatives' public spending targets, which implied very slow expenditure growth and a fall in the share of public spending to gross domestic product (GDP). The conservatism of this policy needs to be seen in the context of the previous period when the Conservative government had pursued policies which led, in the early 1990s, to the largest fiscal deficits in peacetime (surpassing those of the mid-1970s). Even in fiscal year 1996/97 this deficit was still running at 3.5 per cent of GDP, an exceptionally high level by post-war standards. Not only that, but because of the squeeze on public investment dating back to the mid-1970s, these deficits were funding current government spending. In these circumstances, credibility, as New Labour saw it, required the continuation of fiscal tightening, a policy consistent with continuing overall expansion because of the buoyancy of the economy. From 1998/99 this combination of economic buoyancy and fiscal tightening had led to an overall fiscal surplus for only the fifth time since the end of post-war reconstruction at the beginning of the 1950s.

A doubling of the share of GDP to be spent on public investment (from 0.6 to 1.2 per cent of GDP) was announced in 1998, and more broadly it was planned to increase health spending by 4.7 per cent per annum over the 1999-2002 period (in real terms) and education by 5.1 per cent, though the total growth in public spending was fixed at 2.75 per cent per annum. ${ }^{116}$ Brown's 2000 Budget Statement included further pledges, 'our fiscal rules enable us to increase current public spending by 2.5 per cent a year in real terms for the 3 years from 2001 and double net public investment as a share of national income from 0.9 per cent next year to 1.8 per cent in $2004 .{ }^{, 117}$ As well as redressing a past investment shortfall, this was also justified in terms of discretionary fiscal policy seeking to mitigate the effects of the economic cycle, or 'coarse tuning' as outlined above. As Brown pointed out in his 2004 Budget Statement:

fiscal policy can and must take account of the economic cycle - supporting monetary policy by allowing borrowing to rise when the economy grows below trend and reducing borrowing when the economy is above trend ... [thus] it was in the national interest ... to enable fiscal policy during the recent world downturn to support monetary policy ...

this was followed by a commitment 'on the basis of low public debt, to borrow for investment to strengthen our economic fundamentals'. ${ }^{118}$

But the government learnt a lesson that its predecessors had also had to endure changing direction in public spending cannot be achieved overnight. This was testimony to the coarseness of the tuning exercise under way, but did not detract from the fact that the planned public spending increase was intended to be and indeed proved broadly counter-cyclical. In consequence, the recession was offset not just by the automatic stabilizers but also by the delayed but intended expansion of spending. Part of this

115 Christopher Allsopp and David Vines, 'The Assessment: Macroeconomic Policy', Oxford Review of Economic Policy, 16 (2000), 1-32.

116 Treasury, Comprehensive Spending Review and New Public Spending Plans 1999-2002 (London: HM Treasury, 1998); William Keegan, The Prudence of Mr Gordon Brown (Chichester, Sussex: Wiley, 2004), p. 286.

117 Gordon Brown, 'Chancellor of the Exchequer's Budget Statement, 21 March 2000', http://www.hmtreasury.gov.uk/budget/budget_2000/bud_bud00_speech.cfm.

118 Gordon Brown, 'Chancēllor of the Exchēquer's Budget Statement, 17 March 2004', http://www.hmtreasury.gov.uk/budget/budget_04/bud_bud04_speech.cfm. 
intentional discretionary increase in spending was also targeted in a manner consistent with Keynesian thinking - namely redistribution towards those lower earners assumed to have a higher propensity to spend. Higher transfer payment spending in this period was directed towards lower income families with children, and lower income pensioners. ${ }^{119}$ Public spending as a share of GDP bottomed-out in the fiscal year 1999/2000 at 37.1 per cent, thereafter rising sharply to 39.6 per cent by $2002 / 03$. The projected increase announced in 2002 for the period to $2005 / 06$ was, in real terms, over $£ 90$ bn, taking the share of GDP to 41.9 per cent. ${ }^{120}$

Such fiscal policies have to be viewed in the context of New Labour's golden rules, set out in 1997 and central to the search for long-term credibility. ${ }^{121}$ These rules were two fold. One was that over the cycle, public borrowing should only be for investment expenditure and not to pay for current expenditure. A number of things are noteworthy about this rule. First, like so much of New Labour's economic policy positions, it was both grounded in doctrine, but also in an explicit critique of previous policy. One doctrinal point was simply that the beneficiaries of public spending should pay for it; if current spending, then current taxpayers should pay, if investment for the future, then future taxpayers should pay via borrowing. More significantly, however, there was also an explicit doctrinal rejection of the neo-liberal 'fiscal constitution' discussed above. ${ }^{122}$ As Brown pointed out in 2004, when justifying the contra cyclical fiscal policies which countered the world downturn, 'I will not neglect the need for long-term investment and impose an annual balanced budget rule - which would cut spending regardless of the debt level or the economic cycle'. ${ }^{123}$ The critique of past policy was aimed at the whole period since the mid 1970s, during which there was both a sharp downward trend in public investment and an unwillingness to raise taxes to pay for all current spending. The result was that for all the years $1974 / 75$ to $1987 / 88$, and $1991 / 92$ to $1997 / 98$ there was borrowing to pay for current spending, and much in excess of anything that could be justified as cyclical in character. $^{124}$

By contrast, if the policy was restrictive compared with the two previous decades, by both historic and comparative standards it is not a very conservative rule. In the alleged heyday of Keynesianism in the 1950s and 1960s, this rule was kept to. ${ }^{125}$ In comparative terms the rule was also notably less restrictive than that of the Stability and Growth Pact (SGP), which originally set a ceiling of 3 per cent of GDP without regard to the current/capital distinction or to the need to make the calculation cover a full economic cycle. ${ }^{126}$ Thirdly, this rule logically left room for a very substantial expansion of public investment financed by borrowing. This indeed is what Labour embarked upon, attempting to reverse the pattern of the 1980s and 1990s when public investment had been cut to the

119 Carl Emmerson and Christine Frayne, Public Spending Election Briefing 2005 (London: Institute for Fiscal Studies, 2005), p. 4.

${ }^{120}$ Treasury, 2002 Spending Review - New Public Spending Plans 2003-2006 (London: HM Treasury, Cmd $5570,2002)$.

${ }^{121}$ Treasury, Financial Statement and Budget Report, 1997 (London: HM Treasury, 1997).

122 Buchanan and Wagner, Democracy in Deficit.

123 Brown, 'Chancellor of the Exchequer's Budget Statement, 17 March 2004'.

124 Balls and O'Donnell, Reforming Britain's Economic and Financial Policy, pp. 162-4. The figures for the mid 1970s are disputed - see Middleton, Charlatans or Saviours? p. 111.

125 Middleton, Government Versus the Market, p. 111; Peter Clarke, 'Keynes and Keynesianism', Political Quarterly, 69 (1998), 297-305.

126 Clift and Tomlinson, 'Fiscal Policy and Capital Mobility'. 
bone. ${ }^{127}$ Fourthly, it should be noted, the specification of the rule as operating over the cycle left considerable room for manœuvre as to exactly how the dating of that cycle was to be determined. This room to manœuvre was duly exploited by the chancellor. On 19 July 2005, Brown reported to the Treasury select committee that, in the light of revised Office of National Statistics evidence of 'significantly faster growth' between 1997 and 2000, he had 'updated' the hitherto 'provisional judgment that the current economic cycle started in 1999-2000'; 'With the average figure for growth between 1997 and 2000 previously assessed at 2.6 per cent, but now known to be 3.5 per cent, all the evidence now points to the conclusion that the economic cycle started in 1997-1998. ${ }^{128}$ The significance of this is that it allows the chancellor approximately $£ 10$ bn additional surplus to feed into his calculations of whether the 'golden rule' is met over the cycle.

The other fiscal rule announced was that over the cycle the public debt should be held at a stable and prudent level. This again has a theoretical rationale, essentially to guard against a shock to the economy leading to a debt surge, possibly combined with sharp rises in interest rates, making the debt unsustainable. ${ }^{129}$ Importantly, this rationale for low public debt, like other policies for credibility, can be justified as allowing more room for discretion in policy if the economy is subject to shocks: 'if the debt level is not maintained at low levels during favourable economic times, there will be reduced scope for supporting monetary policy and cushioning the economy when faced with unfavourable shocks'.130 Alongside this case for the debt rule went a critique of previous policy, especially in the mid-1990s when debt had risen as a result of the combination of big deficits and a slow-growing economy. Like the previous rule, that on debt was not particularly conservative judged by long-run patterns (the GDP debt ratio was falling through most of the post-war period, not least because of the effects of inflation). Also, while the 40 per cent figure which Labour suggested as a ceiling was considerably less than the SGP 60 per cent rule, compared with where countries started from the British rule was actually less restrictive. By 2000/01 British debt was down to 31.3 per cent of GDP; in contrast, several of the euro members had debt levels exceeding the 60 per cent level, in the cases of Belgium, Italy and Greece, close to or exceeding the 100 per cent level. ${ }^{131}$

In short, the golden rules would have ruled out little of what had been done in British policy in the post-war years except by New Labour's immediate predecessors. Overall, therefore, if the golden rules brought New Labour credibility, they did so without preventing a big rise in public spending (including both investment and current spending) and a big rise in borrowing. Thus the golden rules were not only compatible with a Keynesian response to the recessionary pressures of the early 2000 s, but actually facilitated such a response by increasing the room for manœuvre in macroeconomic policy.

The scale of that room for manœuvre was never subject to a full-scale test in New Labour's first two terms in office, because the benign world environment meant there were no powerful deflationary forces pressing in on the British economy. To assert Labour's

\footnotetext{
127 Andrew Dilnot and Tom Clarke, 'British Fiscal Policy Since 1939', in Roderick Floud and Paul Johnson, eds, The Cambridge Economic History of Britain, Vol. 3: Structural Change and Growth, 1939-2000 (Cambridge: Cambridge University Press, 2004).

${ }^{128}$ Gordon Brown, uncorrected evidence to the Treasury Select Committee, 19 July 2005, available at http://www.publications.parliament.uk/pa/cm200506/cmselect/cmtreasy/uc399-i/uc39902.htm.

129 Balls and O'Donnell, Reforming Britain's Economic and Financial Policy, pp. 168-75.

130 Balls and O'Donnell, Reforming Britain's Economic and Financial Policy, p. 173.

131 Keegan, The Prudence of Mr Gordon Brown, p. 281; Thierry Latreille, 'Les programmes de stabilité en Europe', La Lettre de L'OFCE, no. 214 (2002), 1-4, p. 3.
} 
'Keynesianism' can therefore not be based on the strongest possible evidence - that the government, faced by a major depression fought it off by determinedly Keynesian policies. Nevertheless, from a different direction, there is some evidence on the perspectives underlying policy to be found in events in 1998 when the commitment to full employment seemed to be threatened not by recession but by fears of inflation, and this episode tested how far the idea of the NAIRU (outlined in the previous section) really would prevent the pursuit of full employment if this was seen as incompatible with low inflation.

In the summer of 1998 the continuing fall in unemployment was clearly identified by the Bank of England as threatening the achievement of its inflation target. The idea of a natural rate underpinned a clear statement that if that target were to be achieved unemployment would have to rise. No number was attached to that increase by the bank, but half a million was a figure suggested in the press. ${ }^{132}$ Authoritative voices in the financial press took up the point, a Financial Times editorial arguing bluntly that: 'unemployment must rise, though how much depends on the speed of labour market response'. ${ }^{133}$ If the NAIRU was firmly believed in, the policy response seemed inescapable: a rise in interest rates. Yet the bank equivocated, partly because of ambiguities in what was happening to wage inflation, but also because of reservations about the underlying NAIRU argument. ${ }^{134}$ By October of that year, despite continuing tightness in the labour market, and no evidence of a slowing in wage inflation, interest rates were cut, not increased, on the basis of what was believed to be happening in the world economy.

This episode demonstrates the difficulties of seeing policy under New Labour as driven by strong adherence to the NAIRU. Undoubtedly, this doctrine did influence policy discussions, and Alan Budd, previously chief economic adviser to Conservative governments, seems to have been particularly influential in urging this approach on the Bank of England when he was appointed to the Bank's Monetary Policy Committee in 1997. ${ }^{135}$ But adherence to the doctrine was never unanimous, even in the bank, so that even the institution tasked above all with fighting inflation proved unwilling to follow through with the logic of the NAIRU argument and push unemployment to its 'equilibrium' level. As Dicks and O'Sullivan note: 'For that, 500,000 people will ultimately be grateful'. ${ }^{136}$

\section{CONCLUSIONS}

How does the above argument relate to criticisms of New Labour's alleged abandonment of Keynesianism? First of all from a historical perspective it is important to be clear about Keynesianism and Old Labour: for New Labour to 'abandon' Keynesianism requires that Old Labour was firmly of that persuasion to begin with. Hay argues that:

New Labour ... is highly distinctive and marks a very significant departure from what it embraced throughout its more traditionally social democratic post-war incarnation. Where its

132 Bank of England, Inflation Report, November (London: Bank of England, 1998), pp. 53-6; Financial Times, 17 July 1998.

133 Financial Times, 13 August 1998; see also Robert Chote, 'Comment and Analysis', Financial Times, 17 August 1998

134 Bank of England, Inflation Report, November, pp. 62-4 and 70-2; Financial Times, 11 September 1998.

135 Geoffrey Dicks and John O' Sullivan, 'Is NAIRU Worth a Can of Beans?' New Political Economy, 6 (1999), 74-8, p. 75.

${ }^{136}$ Dicks and O' Sullivan, 'Is NAIRU Worth a Can of Beans?', p. 78. 
aspirations, if not always its policy positions, were Keynesian, they are now distinctly neo-Keynesian or (by any but the most exacting of definitions) new monetarist. ${ }^{137}$

While noting the important qualifier in the second sentence quoted, this argument still seems to exaggerate the 'Keynesianism' of 'Old Labour'. Detailed studies of the Attlee and the first Wilson governments have shown how their economic policy agendas were dominated much more by notions of planning (albeit in different senses) and rather limited faith in Keynesianism. ${ }^{138}$ The Labour government of the 1970s was perhaps, ironically, in general disposition the most Keynesian, but almost from the beginning (and long before the 1976 International Monetary Fund (IMF) visit) it was eschewing Keynesian policies in the face of the inflation and budget problems. Only after the 1976 IMF stamp of approval was given to its policies, and credibility restored, was it able to pursue a mild Keynesian expansion. $^{139}$

Central to the difficulties of the 1970s Labour government was its room for manœuvre in pursuing full employment. This has been a crucial issue for New Labour and its critics. As noted above, Gordon Brown has made strong claims that this goal remains central, even if the means to achieve it have changed. John Grieve Smith has rightly pointed out that this commitment would appear to be in conflict with some of New Labour's doctrinal support for a vertical Phillips curve. ${ }^{140}$ Thus the Budget Report for 2001 suggested that the economy was "currently operating just above potential ${ }^{141}$ and the implication of the doctrine would be that unemployment should rise not fall. But such doctrinal logic does not seem to have prevailed in policy making. Action aimed at achieving a rise in unemployment to counter the threat of inflation has been neither contemplated nor carried out, unlike under previous Labour governments in, for example, 1966 or 1974.

Such criticisms seem to be grounded in viewing Labour's policies as the simple emanation of a doctrine, a doctrine which in turn is over-simplified. Thus Grieve Smith suggests that Labour has boxed itself in by treating unemployment as a wholly supply-side issue. ${ }^{142}$ In fact, as noted above, the doctrine has always been based on asserting the need to combine demand-side and supply-side policies.

Another accusation against New Labour has been that of 'fiscal passivity'. ${ }^{43}$ Again, this seems to misjudge both doctrine and policy. The pursuit of credibility was expressly concerned to create some space for fiscal activism, and in office such activism has indeed been evident. Equally, the suggestion that the huge increases in health spending 'have not been heralded long in advance and have been justified largely in their own terms as a technical solution to a specific problem, not as part of a coherent reform package, ${ }^{144}$ appears problematic. In fact these increases (along with those in education) have been

137 Hay, 'Negotiating International Constraints', p. 285.

138 Alec Cairncross, Years of Recovery (London: Methuen, 1986); Jim Tomlinson, Democratic Socialism and Economic Policy: The Attlee Years 1945-51 (Cambridge: Cambridge University Press, 1997); Jim Tomlinson, The Labour Governments, 1964-1970, Vol. 3: Economic Policy (Manchester: Manchester University Press, 2004).

139 Kathleen Burk and Alec Cairncross, 'Goodbye Great Britain': The 1976 IMF Crisis (London: Yale University Press, 1992); Jim Tomlinson, 'Economic Policy', in Anthony Seldon and Kevin Hickson, eds, New Labour, Old Labour: The Wilson and Callaghan Governments, 1974-79 (London: Routledge, 2004), pp. 55-69.

140 John Grieve Smith, There Is A Better Way (Wimbledon: Anthem, 2001); see also Hay, 'Credibility, Competitiveness and the Business Cycle in "Third Way" Political Economy', p. 46.

${ }^{141}$ HM Treasury, 'The Budget Report: 2001', http://www.hm-treasury.gov.uk/budget/budget_2001/ budget_report/bud_bud01_repchapb.cfm, Chapter B 'The Economy'.

142 Grieve Smith, There Is A Better Way, pp. 19-23.

${ }^{143}$ Hay, 'Credibility, Competitiveness and the Business Cycle in "Third Way" Political Economy', p. 46.

144 Hay, 'Credibility, Competitiveness and the Business Cycle in “Third Way” Political Economy', p. 49. 
heralded since $1998,{ }^{145}$ and definitely do form part of a strategic thrust in Labour's policies, most obviously evident in the 2001 election manifesto. ${ }^{146}$ What such critics perhaps have most difficulty in accepting is that the consequence of New Labour's 'impressive' performance on credibility has been the possibility and actuality of both huge public spending expansion and fiscal activism. ${ }^{147}$ At the macroeconomic level these are the most striking characteristics of New Labour's policies.

This is not to assert that New Labour's macroeconomic strategy of coarse tuning is wholly unproblematic. The aim of this article has not been to defend New Labour's economic policies, but to define them accurately. On the critical side, the problem of 'boxing in' may arise in a rather different manner than Grieve Smith predicts. New Labour's preference (following Keynes's own) for coarse tuning using public investment as the key mechanism is not a particularly fleet-footed macroeconomic policy lever. The ongoing expansion of public investment until 2007 detailed above may present problems if economic conditions should change. If circumstances were to require a reduction in public spending, the political capital invested in the spending programmes by the Labour government would make this extremely hard to achieve.

There are also questions surrounding New Labour's commitment to full employment. In their period of office both the Labour Force Survey and claimant count have shown a continuation of the tendency evident since the mid-1990s for unemployment to fall. However, the evidence on labour market participation shows continuing low levels, especially amongst males over 50 years old, hugely below those prevalent in the period up to the mid-1970s. The other side of this coin is the huge rise in claims for disability benefit, which represents powerful evidence of hidden unemployment. ${ }^{148}$

It is also wholly plausible to argue that these policies have had a considerable adverse effect on competitiveness. ${ }^{149}$ But that is another issue. It is also, and with more immediate relevance, possible to argue that Labour has been lucky in that its macroeconomic policies have not been tested by a severe recession. This is clearly accurate up to a point, though the policies have allowed Britain to avoid the mild recession felt in France and Germany in 2002/03. ${ }^{150}$ However, it is a somewhat odd exercise to judge a government's policies by its response to a contingency that has not occurred. Like governments in the 1950s and 1960s, New Labour has not had its resolve tested by a major external deflationary pressure. How it would have reacted if such a thing had arisen we cannot know. What we can say is that the policies pursued have been fiscally 'activist', have employed 'coarse tuning' and in that sense can sensibly be defined as 'Keynesian'.

If this conclusion differs from that of many commentators the reasons may be two fold. First, as we suggested at the beginning, many commentators on current social democracy and New Labour's policies work with a very broad definition of 'Keynesian social democracy', which conflates a range of issues that can helpfully be separated. Here we have

145 Treasury, Comprehensive Spending Review and New Public Spending Plans, 1999-2002.

146 Labour Party, 2001 Labour Party General Election Manifesto (London: Labour Party, 2001).

${ }^{147}$ Hay, 'Credibility, Competitiveness and the Business Cycle in "Third Way" Political Economy', p. 50.

148 Steve Nickell, 'The Assessment: The Economic Record of the Labour Government Since 1997', Oxford Review of Economic Policy, 18 (2002), 107-19.

${ }^{149}$ Hay, 'Credibility, Competitiveness and the Business Cycle in "Third Way" Political Economy'; Wynne Godley and Alex Izurieta, The Wrong Set-up? A Critique of British Economic Policy under Labour (Cambridge: Judge Institute, Cambridge University, 2003).

${ }^{150}$ OFCE, 'La Traversée du desert: Perspectives pour l'économie mondiale', La Lettre de L'OFCE, 236 (2003), $1-8$, pp. 3-4. 
attempted to separate out macroeconomic (especially fiscal) policy in pursuit of full employment as the key 'Keynesian' issue. Plainly, our argument on this has no necessary implications for judgements on other aspects of Labour's policies, such as the Private Financial Initiative, or other means of closer relations between the public and private sectors. Secondly, critics of New Labour have struggled to disentangle doctrinal statements from policy implementation. Sometimes criticism of doctrine has seemed to suggest criticism of policy, but, as argued above, this is undermined both by the ambiguities of doctrine, and by the irreducibility of policy to doctrine. Both doctrine and policy matter, but they are not the same thing. 
